\title{
Isolasi dan Karakterisasi Fitase dari Mikroba yang Terdapat pada Pupuk Kompos, Rumen Sapi, Ragi dan Tanah Sawah
}

\author{
Sajidan $^{1}$, A.M.P. Nuhriawangsa ${ }^{2}$, S.Z. Fadhilah $^{1}$, E. Erikawati ${ }^{1}$ dan D. Iryani $^{1}$ \\ ${ }^{1}$ Program Studi Biologi, Fakultas Keguruan dan Ilmu Pendidikan, ${ }^{2}$ Program Studi Peternakan, Fakultas Pertanian, \\ Universitas Sebelas Maret Jl. Ir. Sutami 36A, Surakarta 57126
}

\begin{abstract}
ABSTRAK
Penelitian ini bertujuan untuk mengisolasi dan mengkarakterisasi fitase dari berbagai sumber yang diasumsikan kaya akan senyawa fosfat komplek seperti pupuk kompos, isi rumen sapi dan ragi. Isolasi bakteri penghasil fitase dilakukan dengan menggunakan media LB (Luria Bertani) dengan inkubasi pada suhu $37{ }^{\circ} \mathrm{C}$ selama 16 jam, sedangkan isolasi mikrobia dari ragi menggunakan media PDA (Pottato Dextrose Agar). Ekstrak enzim kasar pada supernatan diperoleh dengan cara sentrifugasi pada kecepatan $5.000 \mathrm{rpm}$ selama 5 menit. Ekstrak enzim kasar dikarakterisasi secara fisik meliputi $\mathrm{pH}$ dan temperatur optimum dan pengaruh efektor logam terhadap aktivitas enzim relatif. Hasil penelitian menunjukkan bahwa isolat B1 dari kompos P88 mempunyai aktivitas relatif optimum pada $\mathrm{pH} 5$, suhu $50{ }^{\circ} \mathrm{C}$ dan dengan aktifator $\mathrm{Zn}^{2+}$ pada konsentrasi $10^{-3} \mathrm{M}$ dan $10^{-4} \mathrm{M}$. Isolat $\mathrm{B} 2$ dari rumen sapi mempunyai aktivitas relatif optimum pada pH 5, suhu $50{ }^{\circ} \mathrm{C}$ dan dengan aktifator $\mathrm{Zn}^{2+}$ pada konsentrasi $10^{-3} \mathrm{M}_{\text {dan }} \mathrm{Mg}^{2+}$ pada konsentrasi $10^{-4}$ M. Isolat B3 dari ragi kecap mempunyai aktivitas relatif optimum pada $\mathrm{pH} 5$, suhu $60{ }^{\circ} \mathrm{C}$ dan dengan aktifator $\mathrm{Mg}^{2+}$ pada konsentrasi $10^{-3} \mathrm{M}$ dan $\mathrm{Fe}^{2+}$ pada $10^{-4} \mathrm{M}$ dan $\mathrm{B} 4$ dari ragi tempe mempunyai aktivitas relatif optimum pada $\mathrm{pH} 5$, suhu $50{ }^{\circ} \mathrm{C}$ dan dengan aktifator $\mathrm{Mg}^{2+}$ pada konsentrasi $10^{-3} \mathrm{M}$ dan $\mathrm{Ca}^{2+}$ pada konsentrasi $10^{-4} \mathrm{M}$.
\end{abstract}

Kata kunci: fitase, $\mathrm{pH}$ optimum, temperatur optimum, efektor logam, isolat

\section{Isolation and Characterization of Microbial Phytase from Compost, Cattle Rumen, Yeast and Rice Field}

\begin{abstract}
This research was aimed to isolate and characterize phytase from different sources of higger phosphat complex compounds (compost, cattle rumen, and yeast). Bacteria of phytase was isolated on Luria Bertani (LB) medium and it was incubated on $37{ }^{\circ} \mathrm{C}$ for 16 hours. Microbe from yeast was isolated on Pottato Dextrose Agar (PDA) medium. Crude enzyme from supernatant was extracted with centrifuge on 5.000 rpm for 5 minutes. Crude enzyme was characterized for optimum $\mathrm{pH}$, temperature, and influence of matalo ion efector on relative activity of enzyme. B1 isolate from $P 88$ compost had optimum relative activity on $\mathrm{pH} 5$, temperature $50^{\circ} \mathrm{C}$ and activator $\mathrm{Zn}^{2+}\left(10^{-3}\right.$ and $\left.10^{-4} \mathrm{M}\right)$. B2 Isolate from cattle rumen had optimum relative activity on $\mathrm{pH} 5$, temperature $50^{\circ} \mathrm{C}$ and activator $\mathrm{Zn}^{2+}\left(10^{-3} \mathrm{M}\right)$ and $\mathrm{Mg}^{2+}\left(10^{-4} \mathrm{M}\right)$. B3 isolated from soy sauce yeast had optimum relative activity on $\mathrm{pH}$ 5, temperature $60^{\circ} \mathrm{C}$, and activators $\mathrm{Mg}^{2+}\left(10^{-3} \mathrm{M}\right)$ and, $\mathrm{Fe}^{2+}\left(10^{-4} \mathrm{M}\right)$. B4 isolated from tempeh yeast had optimum relative activity on $\mathrm{pH} 5$, temperature $50{ }^{\circ} \mathrm{C}$ and activators $\mathrm{Mg}^{2+}$ $\left(10^{-3} \mathrm{M}\right)$ and $\mathrm{Ca}^{2+}\left(10^{-4} \mathrm{M}\right)$.
\end{abstract}

Key words: phytase, optimum pH, optimum temperature, metalo ion efector, isolate. 


\section{PENDAHULUAN}

Fitase merupakan salah satu enzim yang tergolong dalam kelompok phosphatase yang mampu menghidrolisis senyawa fitat (myoinositol (1,2,3,4,5,6) hexakisphosphates) menjadi myo-inositol dan fosfat anorganik. Studi tentang fitase sangat pesat pada bebarapa tahun terakhir karena enzim ini bermanfaat terutama sebagai campuran pakan ternak guna mereduksi senyawa fitat, sehingga pemanfaatan unsur fosfor dalam tubuh ternak non ruminansia menjadi optimal (Greiner et al., 1997), serta guna mereduksi polusi unsur fosfor di lingkungan, sehingga eutrofikasi dipermukaan perairan dapat dicegah (Volfova et al., 1994, dan Shin et al., 2001).

Fitase dapat dijumpai pada tanaman, jaringan tubuh beberapa hewan dan mikroorganisme seperti jamur dan bakteri. Fitase dari mikroorganisme mulai diteliti secara intensif baik yang bertipe ekstraseluler dan intraseluler (Greiner et al., 1993). Fitase dari tanaman sudah diisolasi dan dikarakterisasi berasal dari gandum, kedelai, jagung, rerumputan, bunga lili, padi-padian, kacangkacangan dan wortel. Aktivitas spesifik fitase dari tanaman jauh lebih kecil dibanding fitase dari mikroorganisme (Sajidan, 2004).

Enzim mempunyai tipe tertentu dan memerlukan kondisi ideal untuk melaksanakan fungsinya (Applegate and Angel, 2004). Fitase yang dihasilkan dari bakteri dan jamur mempunyai perbedaan $\mathrm{pH}$ optima, ion metal yang disyaratkan, spesifitas substrat, mekanisme reaksi yang dimungkinkan dan temperatur (Wyss et al., 1999).

Penelitian ini bertujuan untuk mengisolasi dan mengkarakterisasi mikroorganisme penghasil fitase yang terdapat pada pupuk kompos, isi rumen sapi dan ragi.

\section{MATERI DAN METODE}

Materi yang digunakan adalah pupuk kompos P88 yang berasal dari Boyolali, isi rumen diambil dari RPH Jagalan Surakarta, ragi kecap dan ragi tempe.
Isolasi menggunakan media padat dan peremajaan dengan media cair (Volk dan Wheeler, 1984). Ektraksi enzim dengan menggunakan sentrifugasi berdasarkan berat molekul (Ismadi, 1987). Isolasi dengan mengambil cairan dari masing-masing sumber yang telah diencerkan dengan larutan $\mathrm{Na}$ fisiologis (isi cairan rumen dan pupuk kompos) dan ditanam pada media LB padat selama 16 jam pada suhu $37^{\circ} \mathrm{C}$ untuk mendapatkan bakteri dan PDA untuk menghasilkan jamur dari ragi yang akan diamati aktivitas fitasenya.

Inokulan bakteri dan jamur hasil isolasi diremajakan kembali pada media LB cair untuk bakteri dengan inkubasi selama 16 jam pada suhu $37^{\circ} \mathrm{C}$ dan media PDA cair untuk jamur selama 6 hari pada suhu $37^{\circ} \mathrm{C}$. Media cair yang telah diinkubasi disentrifus dengan kecepatan 5.000 rpm selama 5 menit untuk mendapatkan ekstrak kasar enzim dari bakteri maupun jamur.

Ektrak kasar enzim kemudian diuji aktivitas fitasenya dengan cara melihat aktivitasnya dalam mendegradasi ikatan fitat dengan melihat fosfat bebas hasil degradasi. Pengukuran aktivitas dengan metode: $25 \mu \mathrm{l}$ enzim, $125 \mu \mathrm{l}$ susbtrat $(0,4 \%$ Na-fitat dalam $100 \mathrm{mM}$ Na-asetat) diinkubasi pada suhu $37^{\circ} \mathrm{C}$ selama 30 menit. Reaksi dihentikan dengan penambahan larutan STOP (Larutan A: 2,352 g ammonium molibdat dalam $100 \mathrm{ml}$ aquades ditambah $2 \mathrm{ml}$ asam salpeter $\left(\mathrm{HNO}_{3}\right)$. Larutan B: $10 \mathrm{~g}$ ammonium metavanadat dalam $100 \mathrm{ml}$ aquades ditambah $1 \mathrm{ml} 25 \% \mathrm{NH}_{4} \mathrm{OH}$. Larutan STOP: memcampur larutan A, larutan B, asam salpeter dan aquades dengan perbandingan = 1,5:1,5:1:2). Warna kuning dari fosfomolibdat diukur dengan spektrofotometer pada $\lambda 415$ nm (Sajidan, 2002).

Optimasi $\mathrm{pH}$, temperatur dan pengaruh efektor logam diketahui dengan cara melihat aktivitas tertinggi pada berbagai level tersebut (Greiner et al., 1997). pH diamati pada level 3, 4, 5, 6, 7, 8, 9, temperatur dengan $\mathrm{pH}$ optimum pada level $6^{\circ} \mathrm{C}$, RT, 37, 40, 50, 60 dan $70^{\circ} \mathrm{C}$, efektor logam dengan $\mathrm{pH}$ dan temperatur optimum pada level $\mathrm{Zn}^{2+}\left(\mathrm{ZnCl}_{2}\right), \mathrm{Ca}^{2+}\left(\mathrm{CaCl}_{2}\right)$, $\mathrm{Mg}^{2+}\left(\mathrm{MgCl}_{2}\right)$ dan $\mathrm{Fe}^{2+}\left(\mathrm{FeCl}_{2}\right)$ dengan konsentrasi $10^{-3}$ dan $10^{-4} \mathrm{M}$. Aktivitas enzim 
dihitung sebagai persen aktivitas relatif fitase dengan rumus (Absorbansi Terkoreksi Sampel x 100\%) : Absorbansi Terkoreksi Tertinggi, dimana Absorbansi Terkoreksi adalah selisih dari Absorbansi Sampel dan Kontrol.

\section{HASIL DAN PEMBAHASAN}

\section{Optimasi pH}

Hasil optimasi pH tampak pada Tabel 1. Optimum pH pupuk kompos P88, rumen sapi, ragi kecap dan ragi tempe adalah 5 .

Aktivitas enzim dipengaruhi oleh $\mathrm{pH}$ (Linder et al., 1955). Pada kondisi maksimum maka pH enzim optimum (Suharsono,1990). Enzim merupakan protein, dengan adanya perbedaan $\mathrm{pH}$ akan mempengaruhi aktivitasnya, sehingga terjadi perubahan ionisasi enzim pada $S$ atau kompleks ES, sampai mencapai kestabilan (Reed, 1975).

Fitase yang dihasilkan dari jamur, bakteri, tanaman dan hewan mempunyai aktivitas $\mathrm{pH}$ yang berlainan (Sajidan, 2004). Fitase dari jamur mempunyai aktivitas $\mathrm{pH}$ spesifik antara
2,5 sampai 7 (Wyss et al., 1999). pH optimum fitase pada $E$. coli adalah 4,0 dan fitase $K$. pneumoniae sangat aktif pada $\mathrm{pH} 5$ (Sajidan et al., 2005). E. Coli appA stabil pada $\mathrm{pH} 2$ sampai 10 (Golovan et al., 2000). Aktivitas fitase tepung gandum diantara $\mathrm{pH} 5$ sampai 6 dengan temperatur 40 sampai $55{ }^{\circ} \mathrm{C}$ (Bergman et al., 2000).

\section{Optimasi Temperatur}

Hasil optimasi temperatur tampak pada Tabel 2. Temperatur optimum dari pupuk kompos P88, rumen sapi dan ragi tempe adalah $50^{\circ} \mathrm{C}$ dan ragi kecap $60^{\circ} \mathrm{C}$.

Suhu meningkat dapat meningkatkan kecepatan reaksi enzim dan mencapai optimum, kemudian menurun secara tajam (Dionysius et al., 1993). Pada kondisi ini gerakan molekul semakin meningkat, sehingga meningkatkan energi aktivasi yang menyebabkan zat yang bereaksi berada dalam keadaan terangsang, sehingga akan melemahkan ikatan tertentu dan akhirnya akan merubah S menjadi P (produk) (Soeharsono, 1990).

Tabel 1. Aktivitas relatif fitase (\%) dari berbagai level pH pada isolat pupuk kompos P88 (B1), rumen sapi (B2), ragi kecap (B3) dan ragi tempe (B4) pada berbagai level $\mathrm{pH}$.

\begin{tabular}{ccccccc}
\hline \hline Sumber & \multicolumn{7}{c}{ Level pH } \\
\cline { 2 - 7 } & 3 & 4 & 5 & 6 & 7 & 8 \\
\hline B1 & 20,2 & 36,8 & 100 & 80,8 & 40,2 & 39,8 \\
B2 & 33,2 & 39,1 & 100 & 67,9 & 61,6 & 60,5 \\
B3 & 17,4 & 33,9 & 100 & 92,4 & 58,6 & 42,2 \\
B4 & 30,3 & 44,2 & 100 & 93,6 & 64,7 & 51,2 \\
\hline
\end{tabular}

Tabel 2. Aktivitas relatif fitase (\%) dari berbagai level temperatur dari isolat pupuk kompos P88 (B1), rumen sapi (B2), ragi kecap (B3) dan ragi tempe (B4) pada berbagai level temperatur.

\begin{tabular}{cccccccc}
\hline \hline Sumber & \multicolumn{7}{c}{ Level Temperatur $\left({ }^{\circ} \mathrm{C}\right)$} \\
\cline { 2 - 8 } & 6 & 28 & 37 & 40 & 50 & 60 & 70 \\
\hline B1 & 0 & 5,2 & 38,4 & 62,9 & 100 & 61,1 & 0 \\
B2 & 87,4 & 88,7 & 90,4 & 92,1 & 100 & 97,9 & 39,7 \\
B3 & 30,8 & 75,8 & 85,5 & 94,4 & 91,9 & 100 & 84,9 \\
B4 & 65,1 & 72,8 & 80,8 & 81,9 & 100 & 83,8 & 78,6 \\
\hline
\end{tabular}


Fitase mikrobia aktif pada suhu 35 sampai $63^{\circ} \mathrm{C}$ (Wodzinski and Ullah, 1996). Optimasi temperatur fitase $E$. coli pada suhu $50-55{ }^{\circ} \mathrm{C}$ sedangkan fitase $\mathrm{K}$. pneumoniae pada suhu $45-50{ }^{\circ} \mathrm{C}$ (Sajidan et al., 2005). E. Coli appA optimum pada suhu $60^{\circ} \mathrm{C}$ (Golovan et al., 2000). Gen phyA yang dikloning ke $A$. fumigatus dan $A$. niger mampu bertahan pada suhu diatas $100^{\circ} \mathrm{C}$ selama 10 menit dengan $\mathrm{pH}$ 2,5 sampai 7,5 (Pasamontes et al., 1997).

\section{Optimasi Efektor Logam}

Hasil optimasi efektor logam konsentrasi $10^{-3} \mathrm{M}$ tampak pada Tabel 3 . Optimasi efektor logam dari rumen sapi dan pupuk kompos P88 dihasilkan efektor $\mathrm{Zn}^{2+}$ dan ragi kecap dan ragi tempe $\mathrm{Mg}^{2+}$.

Hasil optimasi efektor logam konsentrasi $10^{-4} \mathrm{M}$ tampak pada Tabel 4. Optimasi efektor logam dari rumen sapi dihasilkan efektor $\mathrm{Mg}^{2+}$, ragi kecap $\mathrm{Fe}^{2+}$, ragi tempe $\mathrm{Ca}^{2+}$ dan pupuk kompos P88 $\mathrm{Zn}^{2+}$.

Enzim mempunyai sifat karakteristik dengan adanya sifat katalitik yang diatur oleh ion atau molekul. Ion atau molekul tersebut dapat membantu proses katalik (aktifator) dengan dapat berlangsungnya reaksi enzimatis. Selain itu ion atau molekul juga dapat bersifat kebalikannya (inhibitor) dengan menghambat sifat katalitik enzim (Rahayu, 1991). Enzim mempunyai sifat spesifik terhadap beberapa ion, baik bisa bersifat sebagai aktivator maupun inhibitor. Ada beberapa ion utama yang dapat meningkatkan proses katalitik enzim, diantaranya $\mathrm{Fe}^{2+}, \mathrm{Mg}^{2+}, \mathrm{Zn}^{2+}$ dan $\mathrm{Mn}^{2+}$ (Nelson dan Cox, 2000).

Penambahan $\mathrm{Ca}^{2+}$ dan $\mathrm{Sr}^{2+}$ pada konsentrasi $100 \mathrm{mM}$ dalam Tris- $\mathrm{HCl} \mathrm{pH} 7$ meningkatkan aktivitas fitase dari Bacillus amyloliquefaciens DS11 (Oh et al., 2001). Penambahan $\mathrm{Pb}^{2+}$ sebanyak5 mmol $\mathrm{l}^{-1}$ dapat meningkatkan aktivitas fitase tetapi penambahan $\mathrm{Fe}^{2+}, \mathrm{Fe}^{3+}, \mathrm{Cu}^{2+}, \mathrm{Zn}^{2+}$ dan $\mathrm{Hg}^{2+}$ sebanyak $5 \mathrm{mmol} \mathrm{l}^{-1}$ menghambat aktivitas fitase (Yanke et al., 1999). Aktivitas fitase tinggi jika ditambahkan ion $\mathrm{Ca}^{2+}$ dan $\mathrm{Mg}^{2+}$ (Maenz, 2001).

Tabel 3. Aktivitas relatif fitase (\%) dari isolat pupuk kompos P88 (B1), rumen sapi (B2), ragi kecap (B3) dan ragi tempe (B4) pada level efektor logam $10^{-3} \mathrm{M}$.

\begin{tabular}{ccccc}
\hline \hline Sumber & \multicolumn{4}{c}{ Level Efektor Logam $\left(10^{-3} \mathrm{M}\right)$} \\
\cline { 2 - 5 } & $\mathrm{Zn}^{2+}\left(\mathrm{ZnCl}_{2}\right)$ & $\mathrm{Ca}^{2+}\left(\mathrm{CaCl}_{2}\right)$ & $\mathrm{Mg}^{2+}\left(\mathrm{MgCl}_{2}\right)$ & $\mathrm{Fe}^{2+}\left(\mathrm{FeCl}_{2}\right)$ \\
\hline B1 & 100 & 40,1 & 97,4 & 72,3 \\
B2 & 75,2 & 71,2 & 73,4 & 45,6 \\
B3 & 58,5 & 56,2 & 100 & 24,9 \\
B4 & 66,5 & 7,3 & 100 & 31,1 \\
\hline
\end{tabular}

Tabel 4. Aktivitas relatif fitase (\%) dari isolat pupuk kompos P88 (B1), rumen sapi (B2), ragi kecap (B3) dan ragi tempe (B4) pada level efektor logam $10^{-4} \mathrm{M}$.

\begin{tabular}{cllll}
\hline \hline \multirow{2}{*}{ Sumber } & \multicolumn{4}{c}{ Level Efektor Logam $\left(10^{-4} \mathrm{M}\right)$} \\
\cline { 2 - 5 } & \multicolumn{1}{c}{$\mathrm{Zn}^{2+}\left(\mathrm{ZnCl}_{2}\right)$} & $\mathrm{Ca}^{2+}\left(\mathrm{CaCl}_{2}\right)$ & \multicolumn{1}{c}{$\mathrm{Mg}^{2+}\left(\mathrm{MgCl}_{2}\right)$} & $\mathrm{Fe}^{2+}\left(\mathrm{FeCl}_{2}\right)$ \\
\hline B1 & 100 & 30,7 & 68,9 & 90.2 \\
B2 & 93,9 & 82,2 & 100 & 91,3 \\
B3 & $-10,7$ & 17,1 & 55,8 & 100 \\
B4 & $-5,1$ & 19,2 & $-11,8$ & $-15,4$ \\
\hline
\end{tabular}




\section{KESIMPULAN}

Bakteri penghasil fitase dapat diisolasi dari pupuk kompos P88 dan isi rumen sapi. Jamur penghasil fitase dapat diisolasi dari ragi kecap dan ragi tempe. Pupuk kompos 88 mempunyai aktivitas fitase $\mathrm{pH}$ optimum 5, temperatur optimum $50{ }^{\circ} \mathrm{C}$ dan efektor logam $10^{-3} \mathrm{M}$ dan $10^{-4} \mathrm{M}$ adalah $\mathrm{Zn}^{2+}$. Isi rumen sapi mempunyai aktivitas fitase $\mathrm{pH}$ optimum 5, temperatur optimum $50{ }^{\circ} \mathrm{C}$ dan efektor logam $10^{-3} \mathrm{M}$ adalah $\mathrm{Zn}^{2+}$ dan $10^{-4} \mathrm{M}$ adalah $\mathrm{Mg}^{2+}$. Ragi kecap mempunyai aktivitas fitase $\mathrm{pH}$ optimum 5, temperatur optimum $60{ }^{\circ} \mathrm{C}$ dan efektor $10^{-3} \mathrm{M}$ adalah $\mathrm{Mg}^{2+}$ dan $10^{-4} \mathrm{M}$ adalah $\mathrm{Fe}^{2+}$. Ragi tempe mempunyai aktivitas fitase $\mathrm{pH}$ optimum 5 , temperatur optimum $50{ }^{\circ} \mathrm{C}$ dan efektor logam $10^{-3} \mathrm{M}$ adalah $\mathrm{Mg}^{2+}$ dan $10^{-4} \mathrm{M}$ adalah $\mathrm{Ca}^{2+}$.

\section{DAFTAR PUSTAKA}

Applegate, T. J. dan R. Angel 2004. Phytase: Basics of Enzme Function. E-book: Farm Animal Management at Purdue. Departement of Animal Science. Purdue University.

Bergman, E. L., K. Autio dan A. S. Sandberg, 2000. Optimal conditions for phytate degradation, estimation of phytase activity and localization of phytate in barley (Cv. blenheim). J. Agric. Food Chem. 48:46474655.

Dionysius, D. A., K. S. Hoek, J. M. Milne dan S. L. Slattery, 1993. Trypsin-like enzyme from Sand Crab (Portunus pelagicus): Purification and characterization. J.Food Sci. 58:780-784.

Golovan, S., G. Wang, J. Zhang dan C. W. Forsberg, 2000. Characterization and overproduction of the E. coli appA encoded bifunctional enzyme that exhibits both phytase and acid phosphatase activities. J. Can. Microbiol. 46:59-71.

Greiner, R., E. Haller, U. Konietzny, and K.D. Jany. 1993. Purification and characterization of two phytases from Escherichia coli. Arch. Biochem. Biophys. 303: 107-113.

Greiner, R., E. Haller, U. Konietzny, and K.D. Jany. 1997. Purification and characterization of a phytase from Klebsiella terrigena. Arch. Biochem. Biophys. 341: 201-206.

Ismadi, H. M., 1987. Metoda Analisis Enzimatis. PAU Bioteknologi, Universitas Gadjah Mada, Yogyakarta.

Linder, M., Fanni, M. Parmentier, M. Sergent dan R. P. T. Luu, 1995. Protein recorvery from veal bones by enzymatic hydrolysis. J. Food Sci. 60: 949-952.

Maenz, D. D., 2005. Enzymatic Characteristic of Phytases as They Relate to Their Use in Animal Feeds. In E-Book: Enzyme in Animal Nutrition. M. R. Bedford dan G. G. Partridge, Eds. CABI Pub., UK.

Nelson, D. L. dan M. M. Cox, 2000. Lehninger Principles of Biochemistry. 3rd ed. Worth Pub., New York.

Oh, B. C., B. S. Chang, K. H. Park, N. C. Ha, H. K. Kim, B. H. Oh, and T. K., Oh, 2001. Calcium-Dependent Catalytic Activity of a Novel Phytase from Bacillus amyloliquefaciens DS11. J. Biochemistry. 40: 9669-9676.

Pasamontes, L., M. Haiker, M. Wyss, M. Tessier dan Van Loon, 1997. Gene cloning, purification and characterization of a heatstable phytase from fungus A. fumigatus. J. App. Envi. Microbiol. 63: 1696-1700.

Rahayu, K., 1991. Teknologi Enzim. Pusat Antar Universitas Pangan dan Gizi, Universitas Gadjah Mada, Yogyakarta.

Reed, G., 1975. Enzmes in Food Processing. Academic Press, New York.

Sajidan. 2002. Molekulare Characterisierung einer Phytase (Myo-inositol Hexakiphosphate Hydrolase) und von Phosphatasen aus Bakterieisolaten Indoneschicher Reisfelder (Klebsiella pneumoniae). Dissertation. Institut fuer Biologie. Humboldt Universität zu Berlin. Deutschland (Germany).

Sajidan, 2004. Aplikasi Enzim Fitase untuk Campuran Pakan Ternak Unggas. Dalam: Seminar Nasional Sosialisasi dan Promosi Hasil Penelitian. UNS, Surakarta.

Sajidan, A.M.P. Nuhriawangsa dan A. Ratriyanto, 2004. Aplikasi Bakteri Penghasil Fitase (non rekombinan) pada Pakan Campuran Wheat Pollard terhadap Performan Ayam Broiler. 
Buletin Peternakan UGM . Vol. 28(3): 114121.

Sajidan, A. M. P. Nuhriawangsa dan A. Ratriyanto, 2005. Aplikasi Eschericia coli dan Klebsiella pneumoniae Penghasil Fitase dan Kombinasinya pada Pakan Campuran Wheat Pollard terhadap Performan Ayam Broiler. Dalam: Proseding Seminar Nasional Pengembangan Usaha Peternakan Berdaya Saing di Lahan Kering. UGM, Yogyakarta: 186-192.

Shin, S., N.C. Ha, B.C. Oh, T.K. Oh, and B.H. Oh. 2001. Enzyme mechanism and catalytic property of $\beta$ propeller phytase. Structure. 9:851-858.

Suharsono, 1990. Enzimologi. PAU Pangan dan Gizi, Universitas Gadjah Mada, Yogyakarta.
Volfova, O., J. Dvorakova, A. Hanzlikova dan A. Jandera, 1994. Phytase from A. niger. J. Folia Microbiology. 39:481-484.

Volk W.A. dan M.F. Wheeler, 1984. Basic Mikrobiology. Edisi ke-5. Penterjemah: Markham. Penerbit Erlangga, Jakarta.

Whyss., M., R. Brugger, A. Kronenbegger, R. Remy, R. Fimbel, G. Oesterhelt dan M. Lehmann, 1999. Biochemical characterization of fungal phytase (myoinositolhexakisphosphat phosphohydro-lase: Catalytic properties. J. App. Environ. Mirobiology. 65:367-373.

Yankee, L. J., L. B. Selinger, and K. J. Cheng, 1999. Phytase activity of Selenomonas ruminantium: a preliminary character-ization. J. App. Microbiology. 29: 20-25. 